\title{
Erratum to: Abacavir/Dolutegravir/Lamivudine Single-Tablet Regimen: A Review of Its Use in HIV-1 Infection
}

\author{
Sarah L. Greig ${ }^{1}$ Emma D. Deeks ${ }^{1}$
}

Published online: 14 March 2015

(C) Springer International Publishing Switzerland 2015

\section{Erratum to: Drugs}

DOI 10.1007/s40265-015-0361-6

Reviewer names: The spelling of U. Sandovsky was incorrect and should appear as U. Sandkovsky.

The online version of the original article can be found under doi: 10.1007/s40265-015-0361-6.

Sarah L. Greig

demail@springer.com

1 Springer, Private Bag 65901, Mairangi Bay, 0754 Auckland,

New Zealand 